\title{
Computer Vision Used to Monitor The Youth during The Pandemic Covid-19
}

\section{Computer Vision digunakan untuk Memantau Pemuda di Masa Pandemi Covid-19}

\author{
Salsyabila Vidia Nur Afni ${ }^{1}$, Esi Putri Silmina ${ }^{2}$, Irwanda Budi Pangestu ${ }^{3}$ \\ \{salsyabila80@gmail.com ${ }^{1}$, esiputrisilmina@unisayogya.ac.id², irwandabudi@gmail.com ${ }^{3}$ \} \\ Program Studi Teknologi Informasi. Fakultas Sains dan Teknologi. Universitas 'Aisyiyah Yogyakarta1,2,3
}

\begin{abstract}
Computer Vision is a field that studies methods for capturing numerical or symbolic information. Some of the computer vision processes are image capture, image enhancement, segmentation, feature extraction, and clarification. AI-based Computer Vision technology allows the public to carry out more optimal surveillance to deal with Covid-19. During the Covid-19 pandemic, many people have adopted new normal habits by implementing health protocols. But not a few of our people do not understand the importance of implementing health protocols. Where after this year's Eid homecoming, not a few of our people have made trips to their hometown villages. In this case, there is already a prohibition from the Government not to make the Eid homecoming trip. These communities can be at risk of transmitting the Covid-19 virus to their families in their hometowns. This study describes how Computer Vision works in helping the community to monitor travelers from the city to minimize the spread of Covid-19. The paper wa presented using the literature review method. From the description result using the literature review, it has result that computer vision technology has enormous potential in spreading countermeasures Covid-19.
\end{abstract}

Keywords - computer vision; Covid-19

Abstrak. Computer Vision adalah bidang ilmu yang mempelajari metode untuk menangkap informasi numerik ataupun simbolik. Beberapa proses computer vision adalah penangkapan citra, peningkatan citra, segmentasi, ekstraksi fitur, dan klarifikasi. Teknologi Computer Vision berbasis AI memungkinkan masyarakat dalam melakukan pelakukan pengawasan secara lebih optimal untuk menghadapi Covid-19. Dimasa pandemi Covid-19, banyak masyarakat yang sudah melakukan kebiasaan new normal dengan menerapkan protokol kesehatan. Tetapi tidak sedikit dari masyarakat kita yang belum memahami lebih penting dalam penerapan protokol kesehatan. Dimana pasca mudik lebaran tahun ini tidak sedikit dari masyarakat kita yang melakukan mudik perjalanan ke kampung halaman. Dalam hal tersebut sudah ada pelarangan dari Pemerintah untuk tidak melakukan perjalanan mudik lebaran. Masyarakat tersebut dapat beresiko menularkan virus Covid-19 bagi keluarganya di kampung halaman. Penelitian ini mendiskripsikan bagaimana kerja Computer Vision dalam membantu masyarakat untuk memantau pemudik dari kota guna meminimalisir penyebaran Covid-19. Penelitian ini disajikan menggunakan metode literature review. Dari hasil deskripsi menggunakan literature review mendapatkan hasil bahwa teknologi Computer Vision mempunyai potensi yang besar dalam penanggulangan penyebaran Covid-19.

Kata Kunci - computer vision; Covid-19

\section{Pendahuluan}

Melihat fenomena pandemi Covid-19 saat ini, mengaharuskan untuk menerapkan protocol kesehatan dan menerapkan kebiasaan new normal. Tidak sedikit dari masyarakat kita melakukan mudik lebaran di masa pandemi Covid-19. Dimana kegiatan tersebut sangat beresiko dalam penularan virus Covid-19.

Computer Vision merupakan sebuah studi yang fokus pada permasalahan untuk membantu komputer agar bisa melihat seperti manusia. Pada tingkat abstrak, tujuan masalah Computer Vision adalah mengguanakan data gambar yang diamati untuk menyimpulkan sesuatu tentang dunia [1].

Bidang ini merupakan sub bidang Artificial Intelegence dan Machine Learning, di berbagai wilayah di Indonesia tidak sedikit dari masyarakatnya melakukan mudik lebaran. Diduga kurangnya dari pengawasan perangkat desa dalam menerapkan kebijakan yang sudah dibuat oleh pemerintah, sehingga masyarat dapat melakukan mudik lebaran.

Perangkat desa membuat kebijakan dalam memantau masyarakat yang melakukan perjalanan mudik dengan bantuan Computer Vision. Dengan teknologi Computer Vision dapat mudah ketika mendapatkan input dari deteksi wajah dan perilaku masyarakat yang belum menerapkan protokol kesehatan. Computer Vision ini dikembangkan dengan kemampuan pengenalan masyarakat dari kota yang melakukan mudik di desa-desa dan membedakan masyarakat lokal atau tidak.

Melihat dari hal tersebut dampak dari bantuan Computer Vision tersebut dapat meminimalisir penyebaran Covid19 di masyarakat dan dapat memantau masyarakat dalam menerapkan protocol kesehatan. 


\section{METODE}

Metode yang digunakan dalam kajian ini adalah metode Study Literature Reviews. Literature Reviews bertujuan untuk mengetahui struktur intelektual dari kebutuhan lapangan yang diidentifikasi secara mapping, konsolidasi, dan mengevaluasi. Berdasarkan studi tersebut, kesenjangan pengetahuan utama dan peluang untuk mengatasinya teridentifikasi. Alasan utama yang mendasari adalah untuk mengembangkan dan memperluas pengetahuan yang ada di lapangan.

\section{Hasil dan Pembahasan}

\section{AI Computer Vision untuk Monitor Perilaku Masyarakat di Masa Pandemi}

Tujuan dari Computer Vision adalah untuk memahami isi gambar digital. Biasanya, ini melibatkan metode pengembangan yang mencoba mereproduksi kemampuan penglihatan manusia dengan terlebih dahulu memberikan data training yang tepat. Memahami konten gambar digital bisa dengan melibatkan eksplorasi informasi dari deskripsi gambar, yang mungkin berupa objek, deskripsi teks, model tiga dimensi, dan sebagainya.

Computer Vision pada dasarnya mencoba meniru kinerja visual manusia. Human vision sesungguhnya sangat kompleks, manusia melihat objek dengan indera penglihatan lalu obyek citra diteruskan ke otak untuk diinterpretasi sehingga manusia mengerti objek apa yang tampak dalam pandangan matanya. Hasil interpretasi tersebut ini mungkin digunakan untuk mengambil suatu keputusan. Sebagaimana layaknya mata dan otak, Computer Vision adalah suatu sistem yang mempunyai kemampuan untuk menganalisis objek secara visual, setelah objek yang bersangkutan dimasukkan dalam bentuk citra [1].

Konteks Covid-19, perangkat atau aplikasi IoT Computer Vision ini yang diaktifkan atau ditautkan digunakan untuk menurunkan kemungkinan penyebaran Covid-19 kepada orang lain dengan melalui diagnosis dini, memantau pasien, dan protokol setelah pemulihan pasien. Deteksi dan diagnosis dini dapat menyebabkan lebih sedikit infeksi dan sebagai hasilnya, layanan kesehatan yang lebih baik untuk pasien yang terinfeksi [8].

Pemanfaatan teknologi Artifical Intelegence dalam memonitor perilaku masyarakat di masa pandemik dalam pengendalian Covid-19. Dalam kasus ini difokuskan dalam pengawasan masyarakat yang telah melakukan mudik lebaran ke kampung halaman. Dengan bantuan teknologi Computer Vision dapat membantu masyarakat apabila diimplementasikan dengan benar. Masyarakat dapat terbantu dengan adanya informasi dan peringatan dari monitor tersebut adanya masyarakat luar yang datang di kota tersebut dan masyarakat yang tidak menerapkan protokol kesehatan.

Penggunaan perangkat tersebut akan sangat membantu dalam proses pengawasan. Karena dapat mendeteksi perilaku masyarakat untuk memaksimalkan pencegahan virus Covid-19. Dengan adanya kesadaran masyarakat melalui peningkatakan pemberitahuan informasi masyarakat yang melakukan mudik lebaran ataupun masyarakat yang menunjukkan gejala. Selain itu, dengan monitor tersebut waktu pengawasan yang dilakukan lebih efisien.

Sesuai dengan kebutuhan masyarakat ditengah-tengah wabah Covid-19 saat ini, teknologi Computer Vision sangat membantu dalam mengidentifikasi dengan cepat bagaimana perilaku masyarakat di dalam maupun di luar rumah. Hal tersebut menjadi dasar dalam pengawasan epidomologi secara digital. Bantuan teknologi computer vision dapat juga memonitor dalam mengestimasi jarak antarmanusia dan menghitung jumlah manusia yang terekam dalam monitor tersebut. Tujuannya untuk mencegah adanya masyarakat pendatang maupun masyarakat tersbut sudah menerapakan physical distancing atau tidak. Harapan menggunakan alat monitor tersebut dapat melakukan tracing setiap pergerakan masyarakat.

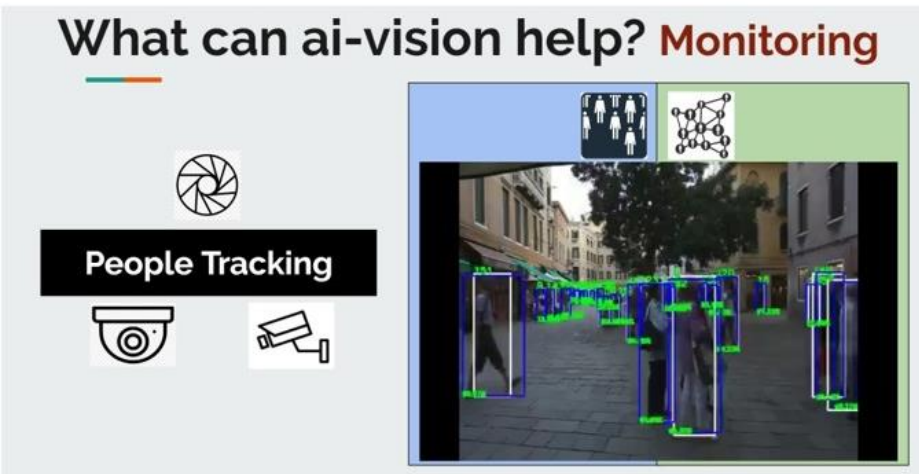

Gambar 1. Model AI-Vision dari Pusat AI ITB untuk kesejahteraan dan keamanan masyarakat [2] 
Penggunaan teknologi Machine Learning dapat dilakukan pengendalian transmisi lokal dalam mengolah citra gambar video melalui drone yang dilengkapi sensor Computer Vision. Hal tersebut digunkan untuk mengamati dan mengidentifikan masyarakat dengan gangguan pernafasan menular dari jarak jauh.

Drone tersebut dipasang dengan sensor khusus dan sistem Computer Vision yang dapat memantau suhu dan detak jantung citra gambar manusia yang terscan dari drone. Dan dilengkapi dengan kemampuan mendeteksi orang bersin dan batuk di ruang publik.

Penelitian ini dilakukan oleh Tim Pusat AI ITB telah berhasil membangun model dengan Single Short Detector (SSD) dan Deep Convolution Neural Network (CNN). Data Training yang digunakan dengan memasukkan dataset berupa ratusan ribu wajah-wajah lokal Indonesia dan atribut lainnya yang ada. Untuk referensinya, kamera pertama akan mendeteksi wajah, kemudian sistem akan mengaklasifikasikan wajah apakah memakai masker atau tidak, apabila tidak memakai masker sistem akan mendeteksi berdasarkan database yang ada. Selain itu, pusat Artificial Intelegence ITB juga telah melakukan model untuk mengetimasi jarak antar manusia dan menghitung jumlah masyarakat yang terekam di dalam maupun di luar ruangan. Tujuannya untuk melihat apakah masyarakat sudah menerapkan physical distancing atau tidak. Dalam pengimplementasiannya membutuhkan segementasi citra yang dapat memecah suatu proses citra digital menjadi banyak segmen atau bagian daerah yang tidak saling bertabrakan dalam konteks citra digital daerah hasil segemntasi tersebut merupakan kelompok piksel yang saling berhubungan [2].

Ssegmentasi citra akan membagi suatu citra menjadi daerah-daerah atau objek yang dimilikinya. Dengan beberapa pendekatan, diantaranya pendekatan daerah yang bertujuan untuk membagi citra dalam daerah-daerah sehingga mendapatkan sutu daerah yang diinginkan. Dengan segmentasi tersebut alat tersebut dapat mendeteksi manusia yang menggunakan masker atau tidak menggunakan masker.

Artificial Intelegence komputer juga dapat digunakan untuk mengukur suhu tubuh. dengan melakukan monitoring deteksi wajah manusia dapat mengetahui suhu tubuh manusia. Pada perkembangan Machine Learning juga digunakan dalam upaya pengawasan gejala secara online tanpa perlu berkunjung. DKI Jakarta meluncurkan fitur Corona Likelihood Metric (CLM) dalam platform JAKI. Yang dikembangkan bersama dengan beberapa relawan peneliti dari Havard CLM Team [7].

Aplikasi ini bertujuan untuk membantu pengguna dalam mengukur resiko kemungkinan terpapar Covid-19 dan membantu pengguna dalam mengukur resiko terjakit virus Covid-19. Selain CLM, perusahaan swasta yang menegembangkan platform pendeteksian gejala penyakit, menggunakan teknologi Machine Learning untuk pendeteksian penyakit lebih awal dengan sisten periksa gejala berbasis Artificial Intelegence bernama Prixa AI [8].

Apabila penggunaannya digunakan dengan benar, maka berdampak besar pada pemutusan rantai Covid-19. Alat tersebut dapat digunakan secara realtime sehingga bisa digunakan untuk khalayak umum dan keperluan pengontrolan kedispilnan penerapan protokol kesehatan salah satunya social distancing dan memakai masker. Sistem yang dibangun secara kontibel sehingga diterapkan secara kontroler dengan bahasa pemrograman dan perangkat yang dibutuhkan. Alat tersebut dapat diintegrasikan dengan peralatan elektronik lainnya sebagai aksi setelah pemantauan dan pendeteksian yang dilakukan.

Penerapan teknologi Computer Vision dan Machine Learning tidak hanya memonitoring tetapi juga bisa digunakan dalam upaya untuk mendeteksi dampak pandemi Covid-19 terhadap kesehatan mental. Dalam studi yang dilakukan oleh Astuti [10], ditemukan bahwa penghitungan data statistik kesehatan mental bisa dilakukan dengan menganalisis data dari media sosial.

Diharapkan dengan adanya alat tersebut dapat mencegah penanggulangan Covid-19 serta dapat membantu masyarakat dalam menerapkan kehidupan new normal guna memutus rantai penyebaran Covid-19.

\section{KESIMPULAN}

Berdasarkan studi literatur yag dilakukan, dapat disimpulkan bahwa teknologi Computer Vision mempunyai potensi yang besar dalam penanggulangan penyebaran Covid-19. Dalam tulisan ini dijelaskan bagaimana manfaat dari teknologi yang ada pada computer Vision. Teknologi Computer Vision dapat digunakan untuk memantau masyarakat dalam berperilaku secara new normal sesuai protokol keseshatan. Bagaimana masyarakat dalam melakukan social distancing, dan dalam penggunaan masker. Tidak hanya itu, dengan teknologi Computer Vision dapat membantu masyarakat dalam memonitor masyarakat yang berpergian ke kota lain atau sebaliknya.

Covid-19 menjadi krisis kesehatan dan sosial sebagai ancaman global. Social disctancing yang diberlakukan serta larangan berpergian ke luar kota dalam menanggapi Covid-19 telah berdampat buruk bagi berbagai sektor. Namun terdapat banyak upaya yang bisa dilakukan untuk menanggulangi penyebaran Covid-19 tersebut. Dengan memanfaatkan perkembangan teknologi Computer Vision secara efisien dapat memberikan dapak yang signifikan dalam penanggulangan pandemi Covid-19. Dengan menerapkan teknologi dengan benar dengan cara yang aman lebih banyak masyarakat dapat dengan leluasa berpartisipasi dalam menggunakan perangkat Computer Vision.

Di masa yang akan datang, penerapan perkembangan teknologi khususnya pada computer vision, akan semakin digital, menyadari pentingnya perkembangan teknologi, masyarakat dakan mempersiapkan diri apabila terjadi 
Procedia of Engineering and Life Science Vol. 1. No. 2 Juni 2021

Seminar Nasional \& Call Paper Fakultas Sains dan Teknologi (SENASAINS 2nd)

Universitas Muhammadiyah Sidoarjo

bencana yang tidak diinginkan terjadi lagi. Hal ini dilakukan mengingat bahwa virus tidak mengenal batas wilayah dan waktu. Perlu adanya kesadaran dalam diri kita masing-masing untuk selalu taat dalam menjaga kesehatan badan.

\section{REFERENSI}

[1] RD. Kusumanto, W. S. Pambudi, and A. N. Tompunu. "Aplikasi Sensor Vision untuk Deteksi MultiFace dan Menghitung Jumlah Orang," Seminar Nasional Teknologi Informasi \& Komunikasi Terapan 2012, pp. 26-33

[2] Prince, Simon J.D. 2012. Computer Vision: Models, Learning, and Inference. Cambridge: CUP

[3] Utama, Nugraha Priya, Tim Pusat AI ITB, dan Prosa AI. 2020. Pemanfaatan AI-Computer Vision untuk Monitor Perilaku Masyarakat pada Masa Pandemi. https://stei.itb.ac.id/id/blog/2020/06/04/nugraha-priya-utama-dalamwebinar-pemanfaatan-ai-computer-vision-untuk-monitor-perilaku-masyarakat-pada-masa-pandemi/

[4] D. Susantyo, "Ekstraksi fitur untuk pengenalan wajah pada ras mongoloid menggunakan principal component analysis (pca)," pp. 1-9, 2015

[5] UniSA Media Centre. 2020. UniSA Working on Pandemic Drone to Detect Coronavirus. https://www.unisa.edu.au/unisanews/2020/autumn/story11/

[6] Prosa AI. 2020. Social Media Monitoring COVID-19. https://covid19-socmed.prosa.ai/

[7] Pemerintah DKI Jakarta dan Harvard CLM Team. 2020. Corona Likelihood Metric (CLM): Aplikasi Uji Risiko Mandiri Gejala COVID-19. https://corona.jakarta.go.id/id/clm

[8] Borgia, E. (2014). The Internet of Things vision : Key features, applications and open issues. ComputerCommunications, 54, 1-31.

[9] Prixa AI. 2020. Sistem Periksa Gejala Berbasis AI. https://www.prixa.ai/

[10] Astuti, Fitri Andri and Nisa', Nurul Ainun. 2020. Harnessing Social Media Data to Measuring Mental Health Statistics. UNESCAP: 2020 Asia-Pacific Statistics Week. https://www.unescap.org/sites/default/files/APS2020/49_Harnessing_Social_Media_Data_to_Me asuring_Mental_Health_Statistics_Indonesia.pdf 